\title{
KONGRES TEOLOGÓW POLSKICH
}

\author{
$(21-23$. IX. 1971 r.)
}

$\mathrm{W}^{\top}$ dniach 21-23. IX. 1971 r. odbył się na Katolickim Uniwersytecie Lubelskim Kongres Teologów Polskich. W Kongresie wzięło udział około 380 uczestników, wśród nich Ks. Kard. Karol Wojtyła - Przewodniczący Komisji dla Spraw Nauki Katolickiej przy Konferencji Episkopatu Polski, Księża Biskupi: Kałwa, Ablewicz, Bareła, Mazur, Zaręba, Drzazga, Obłąk, Bejze, Wójcik, Majdański, Jędruszuk, Pylak, Smoleński, Gulbinowicz, Urban, Skomorucha. Obradom przewodniczył Ks. Kard. Wojtyła. Na sekretarzy Kongresu powołano ks. dra Adama Kubisia, zast. prof. na Papieskim Wydziale Teologicznym w Krakowie, oraz ks. doc. dra Remigiusza Sobańskiego z ATK. W pierwszym dniu zasiedli za stołem prezydialnym Ks. Bp J. Obłąk, ks. prof. dr W. Granat, ks. prof. dr K. Kłósak oraz ks. prof. dr St. Łach. W drugim dniu zaproszono do prezydium ks. prof. dra L. Krupę, ks. prof. dra P. Pałkę, ks. prof. dra J. Majkę oraz ks. dra R. Raka. Trzeciego dnia tworzyli prezydium Ks. Bp W. Urban, ks. inf. dr Liedtke, ks. dr B. Waczyński oraz ks. prof. dr E. Kopeć.

Obrady Kongresu poprzedziła Msza św. odprawiona w kościele akademickim przez Ks. Bpa Piotra Kałwę, Wielkiego Kanclerza KUL. Homilię w czasie Mszy św. wygłosił Ks. Kard. K. Wojtyła.

O godz. $11 \mathrm{w}$ auli uniwersyteckiej powitał uczestników rektor KUL ks. prof. dr A. Krąpiec. Obrady otworzył Ks. Kard. K. Wojtyła, który też odczytał list Ks. Kardynała Prymasa, nie mogącego przybyć na Kongres, oraz Księży Biskupów: Baraniaka z Poznania, i Kowalskiego z Pelplina.

Pierwszego dnia wysłuchano referatu Ks. Kard. K. Wojtyły: „Zadania teologów w Kościele posoborowym", oraz komunikatu Ks. Bpa Jana Obłąka o „500 letniej rocznicy urodzin Mikołaja Kopernika”. 
Tematyką centralną Kongresu była antropologia chrześcijańska. Toteż w drugim dniu wysłuchano na zebraniu plenarnym referatu Ks. Bpa dr B. Bejze: „Teologia a antropologia w świetle nauki Vaticanum II”. Aspekt biblijny zagadnienia przedstawił ks: doc. dr K. Romaniuk, aspekt filozoficzny ks. doc. dr M. Jaworski, aspekt teologiczno-systematyczny ks. dr A. Zuberbier. W ostatnim dniu obrad wygłosił referat ks. dr A. Nossol: „Problem integracji w nauczaniu teologicznym".

W dyskusji podczas obrad plenarnych zabrało głos wielu księży profesorów.

W pierwszym dniu (21. IX) chronologicznie mówili: doc. dr S. Sawicki, prorektor KUL; ks. dr J. Frankowski, ATK; ks. dr M. Banaszak, Poznań; doc. dr M. Gogacz, KUL i ATK; ks. dr S. Napierała, Poznań.

W drugim dniu (22. IX) przemawiali kolejno: ks. prof. dr J. Pastuszka, KUL; ks. dr J. Wiśniowolski, Łomża; ks. dr J. Sieg TJ, Kraków; Ks. dr J. Frankowski, ATK; ks. doc. dr W. Hładowski, Drohiczyn; Ks. mgr P. Duda, O.N.P., Obra; ks. dr L. Kostro, Gdańsk; ks. doc. dr L. Kuc, ATK; ks. dr B. Inlender, Warszawa.

W trzecim dniu (23. IX) uczestnikami dyskusji byli: ks. prof. dr J. Stępień, ATK; ks. doc. dr B. Dembowski, ATK; ks. prof. dr S. Kamiński, KUL; ks. dr B. Waczyński, Warszawa; ks. doc. dr W. Hładowski, Drohiczyn; ks. prof. dr A. Krąpiec, rektor KUL; ks. dr Weron, S.A.C.; ks. Bp dr B. Bejze, Łódź i ATK; ks. dr J. Kobylański, Siedlce.

Ponadto niektórzy księża profesorowie złożyli swój głos jedynie na piśmie, bez wypowiedzenia się $\mathrm{w}$ auli. Wypowiedzi te znajdują się $\mathrm{w}$ aktach Kongresu.

W godzinach popołudniowych obradowały sekcje teologiczne, a mianowicie teologii moralnej, dogmatycznej i mariologicznej, biblijnej, filozofii, apologetyki, prawa kanonicznego, psychologii, historii Kościoła, socjologii, teologii pastoralnej, homiletyki, liturgiki, katechetyki, sztuki kościelnej, teologii ascetycznej, muzyki kościelnej, teologii ekumenicznej oraz języka łacińskiego. Również obrady sekcji były miejscem ożywionych dyskusji. Ostatniego dnia Kongresu (23. IX) przewodniczący sekcji lub ich delegaci zreferowali wyniki obrad. Ich sprawozdania zaprezentowane na sali obrad zapoznały uczestników Kongresu z pracami i problematyką prac sekcyjnych, która niekiedy stanowiła pogłębienie i rozwinięcie tematyki posiedzeń plenarnych. Poszczególne sekcje wytypowały też kandydatów do Rady Naukowej przy Komisji dla spraw Nauki Katolickiej Episkopatu Polski.

W trakcie Kongresu doszło także do'spotkania jego uczestników z ks. dr R. Łukaszykiem, sekretarzem naukowym Redakcji Naczelnej Encyklopedii Katolickiej (21. IX), celem poinformowania o pracach nad nią, oraz do spotkania redaktorów teologicznych czasopism naukowych 
z ks. Bp B. Bejze, podczas którego omówiono zagadnienie publikacji materiałów Kongresu (22. IX). Niestety zapowiadane konferencje prasowe nie miały miejsca, pomimo wielu chętnych uczestników, którzy opuścili dwukrotnie przygotowaną $\mathrm{w}$ tym celu salę $\mathrm{z}$ rozczarowaniem.

Kongres dał wreszcie okazję do wielu innych spotkań teologów polskich o charakterze roboczym lub personalnym. Między innymi ks. prof. M. Rechowicz odbył konferencję $\mathrm{z}$ autorami opracowywanej historii teologii polskiej (22. IX). Jednym $\mathrm{z}$ aktów Kongresu było wreszcie przesłanie Ojcu św. Pawłowi VI wyrazów czci i oddania ze strony teologów polskich.

Zostawiając monograficznemu opracowaniu materiały omawianego Kongresu Teologów Polskich zasygnalizujemy tutaj tylko jego ogólną orientację.

Pod adresem głównych referatów sesji plenarnych i dyskusji, która się wokół nich wywiązała, należy stwierdzić, że ukazały wielką aktualność problematyki antropologicznej. Jest ona nakazem chwili, jeżeli się chce, aby filozofia i teologia mogły zainteresować współczesnego człowieka i nawiązać z nim twórczy dialog. Studia nad antropologią chrześcijańską są jeszcze i z tego względu bardzo ważne, ponieważ nauka katolicka nie ma, jak dotąd, odpowiednio wypracowanych koncepcji. Poglądy $\mathrm{i}$ tendencje, jakie $\mathrm{w}$ tym względzie istnieją, są niekiedy niebezpieczne i muszą być odrzucone. W tej sytuacji nie wolno rezygnować z podjęcia prób stworzenia własnej nauki o człowieku która odpowiadałaby jego współczesnym potrzebom i pozostawała w zgodzie $\mathrm{z}$ myślą Objawienia i Kościoła, w szczególności II Soboru Watykańskiego.

Prace sekcji były bardzo zróżnicowane w zależności od przedmiotu zainteresowania i metody badań przez nie reprezentowanych. Do problematyki ogólnej nawiązały przede wszystkim, tak w referatach jak i dyskusji sekcje: filozoficzna, socjologiczna, biblijna, dogmatyczna i homiletyczna. Pracą swoją starały się one zgłębić implikacje antropologiczne $\mathrm{w}$ interesujących je dziedzinach nauki. Inne sekcje, choć bezpośrednio nie włączyły się w nurt tematyki naczelnej, to jednak starały się poruszyć sprawy dla siebie aktualne i to zarówno w wymiarze ogólnokościelnym jak i rodzimym, polskim. Była to praca nie tylko wszerz, o charakterze informacyjnym, ale również wgłąb, ponieważ ukazywała aktualny stan wiedzy w omawianych kwestiach $\mathrm{z}$ uwzględnieniem własnepo dorobku naukowego. 